\title{
СТРАТЕГІЧНА КОНКУРЕНТОСПРОМОЖНІСТЬ ПІДПРИЕМСТВА: ЗМІСТОВНІ ІМПЕРАТИВИ ТА КРИТЕРІЇ ОЦІНЮВАННЯ
}

\section{СТРАТЕГИЧЕСКАЯ КОНКУРЕНТОСПОСОБНОСТЬ ПРЕДПРИЯТИЯ: СОДЕРЖАТЕЛЬНЫЕ ИМПЕРАТИВЫ И КРИТЕРИИ ОЦЕНКИ}

\author{
THE STRATEGIC COMPETITIVENESS: IMPERATIVES CONTENT AND \\ EVALUATION CRITERIA
}

\begin{abstract}
Надано узагальнюючу характеристику категорї конкурентоспроможності та ознак конкурентоспроможного підприємства. На основі розгляду дискусійних положень розуміння змісту стратегічної конкурентоспроможності викладено авторську позицію, що трунтується на конкретизованих ознаках перспективності, тривалості $i$ потениійності розвитку підприємства. До наукової термінології уведено поняття стратегічного періоду, запропоновано його сутнісне визначення та методичні підходи до параметризаиї тривалості стратегічного періоду.

Розглянуто сутнісні ознаки стратегічної конкурентоспроможності підприємства, які складають об'єктну основу визначення ї̈ кількісних характеристик. Запропоновано метод оцінювання стратегічної конкурентоспроможності на основі врахування часу функціонування діючого підприємства, досягнутого рівня конкурентоспроможності та ступеня реалізація підприємством иільових параметрів розвитку у поточному періоді, щзо $y$ формалізованому вигляді спирається на розрахунок коефіцієнтів конкурентного досвіду, досягнутої і динамічної конкурентоспроможності підприємства.

Доведено можливість отримання аналітичних висновків, придатних для визначення управлінських рімень, на основі матричного позиціонування складових стратегічної конкурентоспроможності досліджуваного суб'єкта ринку.

Ключові слова: стратегія, конкурентоспроможність, стратегічна
\end{abstract} конкурентоспроможність, стратегічний період.

Предоставлено обобщающую характеристику категории конкурентоспособности и признаков конкурентоспособного предприятия. На основе рассмотрения дискуссионных положений понимания содержания стратегической конкурентоспособности изложень авторскую позицию, основанную на конкретизированных признакам перспективности, продолжительности и потенщиальности развития предприятия. В научной терминологии введено понятие стратегического периода, предложено его сущнностное определение $u$ методические подходы к параметризации продолжительности стратегического периода.

Рассмотрень сущноостные признаки стратегической конкурентоспособности предприятия, составляющче объектную основу определения ее количественных характеристик. Предложен метод оценки стратегической конкурентоспособности на основе учета времени функционирования действующего предприятия, достигнутого уровня конкурентоспособности и степени реализация предприятием целевых параметров развития в текущем периоде, в формализованном виде опирается на расчет коэффициентов конкурентного опыта, достигнутого и динамической конкурентоспособности предприятия.

Доказана возможность получения аналитических выводов, пригодных для определения управленческих решений, на основе матричного позиционирования составляющих стратегической конкурентоспособности исследуемого субъекта рынка. 
Ключевые слова: стратегия, конкурентоспособность, конкурентоспособность, стратегический период.

The general characteristic of the categories of competitiveness and competitive enterprise features is defined. Having analyzed the discussion issues of understanding the content of strategic competitiveness the author stated his position based on concretized characteristics of sustainability and potentiality of the company. The author introduced to the scientific terminology the concept of strategic period, offered its essential definition and methodological approaches to strategic parameterization of its duration.

Key features of the strategic competitiveness of enterprises which constitute the basis for determining the object base of its quantity characteristic are considered. The method of evaluation of strategic competitiveness is proposed, based on company operating period, reached level of competitiveness and realization by the company its target parameters during the current period that is based on a formalized calculation of the coefficients of competitive experience, reached and dynamic competitiveness of the company.

The expediency of obtaining analytical conclusions useful for determining management decisions based on matrix positioning of components of the strategic competitiveness of the studied market subject are proved.

Key words: strategy, competitiveness, strategic competitiveness, strategic period

Вступ. Сучасні дослідження конкурентного середовища охоплюють широкий спектр проблем взаємовідносин суб'єктів ринку, які 3 різною інтенсивністю і формами впливу, відстоюють власні конкурентні інтереси. Визначальною цільовою характеристикою і порівняльною аналітичною ознакою зазначених суб’єктів є їхня конкурентоспроможність. Дане поняття застосовують для характеристики конкурентних можливостей національних економік, галузей, окремих підприємств та продуктів їх виробництва. Різноманітність об'єктів конкурентоспроможності обумовлює різне смислове наповнення конкурентоспроможності, а 3 огляду на велику кількість синонімічних термінів - конкурентна позиція, конкурентний статус, конкурентне положення та інших, робить його розуміння поліформатним 3 ознаками вираженої індивідуальності.

Наукова література відображає безліч спроб визначення суті конкурентоспроможності, їі детермінант, часових та якісно диференційованих форм прояву. Значущість даних проблем підтверджується широкою полемікою, до якої долучились такі відомі дослідники як Дж. Дей, П. Дойль, Д. Ебел Дж. О’Шонесі, Н. Пірсі, М. Портер, Д. Сондерс, Р. Фатхутдінов, Г. Хулей, Д. Ебел та інші, які досліджували теоретичні витоки і прикладні аспекти формування конкурентоспроможності. Усвідомлення складності і багатогранності такого поняття як конкурентоспроможність підприємства, обумовило появу його потенційного, поточного, перспективного, досягнутого форматів, що характеризують корпоративні конкурентні можливості з різних часових позицій. Останнім часом в наукових публікаціях стало використовуватись поняття стратегічної конкурентоспроможності, яке, зазвичай, ототожнюють 3 перспективними параметрами розвитку підприємства, що значно звужує його смислове наповнення. Стратегічна конкурентоспроможність $є$ не лише відображенням конкурентних можливостей суб'єкта ринку у майбутньому, але й 
характеристикою здатностей підприємства, які мають забезпечити його конкурентоспроможність у перспективі.

3 прикладних позицій актуальність забезпечення стратегічної конкурентоспроможності обумовлена зростаючою непередбачуваністю змін зовнішнього організаційного середовища і виключною необхідністю реалізації визначених конкурентних стратегій, що мають сприяти стійкому конкурентному розвитку підприємств у довгостроковій перспективі.

Постановка завдання. Враховуючи визначену актуальність окресленої проблеми, завданням даного дослідження $\epsilon$ з'ясування сутнісних ознак стратегічної конкурентоспроможності, показників та методів іiі оцінювання. Реалізація даного завдання сприятиме створенню теоретико-методологічного базису використання стратегічного формату конкурентоспроможності підприємства в аналітичних і управлінських цілях.

Методологія дослідження. При обгрунтуванні категоріального апарату використовувались методи наукового узагальнення, абстракції, аналогії та синтезу. Методологічною базою визначення передумов оцінювання стратегічної конкурентоспроможності підприємств слугували методи порівняльного та системного аналізу, дедукції, матричного позиціонування.

Результати дослідження. 3'ясування суті стратегічної конкурентоспроможності підприємства має спиратись на розуміння базового поняття - конкурентоспроможності суб'єкта ринку. Не ставлячи за мету здійснення аналізу дискусії 3 цього питання, відзначимо лише основні ऑii положення, які не потребують подальшого обговорення.

Не піддається сумніву обгрунтованість позиції М. Портера щодо суті конкурентоспроможності, яка відображає «властивість суб'єкта ринкових відносин виступати на ринку нарівні 3 присутніми там конкуруючими суб'єктами» [1, с.23]. 3 цього можна зробити висновок, що основною ознакою конкурентоспроможності підприємства $є$ його виробнича діяльність на певному ринку. Буде правильним і похідне твердження - наявність здатності підприємств до конкуренції зберігає їхню присутність на ринку.

Конкурентоспроможність суб'єкта ринку нерозривно пов'язана 3 системою його конкурентних переваг. Вона $\epsilon$ наслідком реалізації наявних переваг, але не складає їхню арифметичну суму. Це нова якісна характеристика організації, що забезпечує їі конкурентний успіх, основою якої слугує комплекс позитивних відмінностей, достатніх для протистояння негативному впливу зовнішнього середовища задля реалізації визначених конкурентних цілей. Зазначимо, що конкурентоспроможність це не лише результат реалізованих конкурентних переваг, а й наслідок конкурентних прорахунків в діяльності суб'єкта конкуренції. Тому предметом дослідження має бути конкурентоспроможність у різних форматах ii прояву, в тому числі i потенційному.

Не менш важливою ознакою конкурентоспроможності є іï відносність, як по відношенню до конкурентів, так і фактору часу.

Перше твердження випливає 3 неможливості відокремленого від конкурентів визначення здатності суб’єкта до конкуренції. 
Конкурентоспроможними стають ті підприємства, які витримують конкурентний вплив суперників і реалізують свою здатність до задоволення потреб споживачів.

Часова відносність конкурентоспроможності означає, що досягнутий в окремий проміжок часу рівень конкурентоспроможності підприємства не може розглядатися як іманентну довгострокову характеристику його ринкової позиції. В даному контексті вартим уваги є думка 3.Є. Шершньової і С.В. Оборської про те, що «конкурентоспроможність організації не $є$ її постійною характеристикою, вона визначає здатність вести успішну конкурентну боротьбу, протистояти у певний період основним конкурентам. Зі змінами у зовнішньому та внутрішньому середовищах змінюються також порівняльні конкурентні переваги щодо інших підприємств галузі» [4, с.71].

Слід також додати, що зміна конкурентоспроможності може відбуватись не лише під впливом управлінських дій даного підприємства (обгрунтованих чи помилкових), а й бути наслідком відповідної діяльності конкурентів. Тому конкурентоспроможність підприємства характеризується високим рівнем мінливості, що потребує формування потенціалу піi підтримання у не сприятливих умовах середовища.

Зазвичай наявність засобів підтримання стійкого розвитку суб'єкта ринку в динамічному середовищі впродовж значимого періоду, пов'язують 3 його стратегічними можливостями, об'єднаними поняттям стратегічної конкурентоспроможності підприємства.

В науковій літературі стратегічну конкурентоспроможність здебільшого пов'язують 3 перспективним характером конкурентного положення суб'єкта ринку, за майже повної відсутності спроб ідентифікувати інші іiі смислові характеристики. Лише деякі вчені долучились до вивчення сутності та з'ясування ознак термінологічного виокремлення поняття стратегічної конкурентоспроможності підприємства.

Так, Р.А. Фатхутдінов зазначає, що стратегічна конкурентоспроможність це «потенційна здатність об'єкта або суб'єкта управління конкурувати в майбутньому на конкретних ринках, яка забезпечується зниженням прояву стратегічних неконкурентоспроможних факторів і посиленням прояву стратегічних ексклюзивних конкурентних переваг об'єкта (суб'єкта) на основі проведення комплексної стратегічної діагностики об'єкта або суб'єкта, параметрів ринку i конкурентів, розробки стратегії» [3, с.34]. Вчений концентрує увагу на перспективному i потенційному форматі стратегічної конкурентоспроможності, підкреслюючи належність ії носія до конкретного конкурентного ринку. Останнє $є$ ознакою безпосереднього зв'язку даного терміну із загальновизнаним розумінням суті конкурентоспроможності суб'єкта ринку. Стратегічна конкурентоспроможність має смисл аналітичного застосування лише по відношенню до ринку, де реалізує свої конкурентні інтереси дане підприємство, а іiі рівень визначається у порівнянні його конкурентного положення з основними конкурентами.

А.C. Шпанко вказує на каузальний зв'язок стратегічної конкурентоспроможності з «ключовими можливостями розвитку» підприємства. 
Проте автор суттєво звужує смислове наповнення даного терміну, ототожнюючи стратегічну конкурентоспроможність 3 виокремленою «ознакою суб'єкта ринку, яка демонструє наявність у нього ключових можливостей розвитку, здобутих шляхом швидкої адаптації внутрішнього середовища функціонування до змін зовнішнього середовища, і досягнення на основі цього конкурентних цілей». [5, с.48].

Дійсно, досягти стратегічної конкурентоспроможності можна лише завдяки реалізації визначальних, «ключових» конкурентних переваг. Але це $\epsilon$ скоріше умовою забезпечення стратегічної конкурентоспроможності, але аж ніяк не їі смисловою характеристикою.

В монографії російських науковців В.С. Рохчина, О.М. Вєтрової і О.В. Полянського стратегічна конкурентоспроможність визначається як «багаторівнева економічна категорія i об'єкт управління, що характеризує здатність об'єктів і суб'єктів конкурентоспроможності протягом тривалого часу зберігати і (або) посилювати свої позиції на глобальних, мультинаціональних і локальних ринках...»[2, с.58]. Дослідники обгрунтовано вказують на необхідність відокремленого вивчення об’єкту управління і економічної категорії, коли мова іде про таке складне економічне явище, що одночасно може розглядатись як елемент наукової теорії і управлінської системи. Але навряд чи доцільно вважати стратегічну конкурентоспроможність окремою економічну категорію, за наявності усіма визнаної категорії конкурентоспроможність. III стратегічний формат $\epsilon$ уточнюючою ознакою, що вказує на певні характеристики загальної системи економічних відносин, що виникають між учасниками спільного конкурентного ринку.

Підкреслимо також обгрунтовану вимогу спільності ринку досліджуваних підприємств. Конкурентоспроможність стає об'єктом прикладного аналізу, коли вона відображає результативність конкурентних зусиль суб'єктів, які $\epsilon$ учасниками спільного конкурентного ринку. Тому позиція авторів щодо диференціації стратегічної конкурентоспроможності підприємства на «глобальних, мультинаціональних i локальних ринках» $\epsilon$ не однозначною, оскільки суб'єктами глобальних ринках є переважно транснаціональні компанії. Малі підприємства не можна вважати учасниками глобальних, чи мультинаціональних ринків, але їхня стратегічна конкурентоспроможність, як характеристика потенційної перспективної здатності зберегти свою присутності на ринку, має право на існування.

Отже, стратегічну конкурентоспроможність науковці пов'язують 3 перспективними, довготривалими i потенційними ознаками конкурентних можливостей суб'єкта, що мають забезпечити його майбутню присутність на ринку. Вони не викликають заперечень, але потребують уточнення, доповнення і системного узагальнення задля поглибленого сприйняття сутності стратегічної конкурентоспроможності підприємства.

Перспективний характер стратегічної конкурентоспроможності, як головної їі ознаки, має щонайменше дві форми фіксації:

- наявну, що характеризується здатністю підприємство до конкуренції за рахунок конкурентних переваг, які збережуться у стратегічній перспективі; 
- майбутню, якої може досягти підприємство в перспективі за рахунок набуття і реалізації нових конкурентних переваг, які б відповідали змінюваним умовам середовища.

В першому випадку стратегічний характер конкурентоспроможності підприємства буде визнаним в разі володіння ним конкурентними перевагами, які не втратять свою силу у стратегічній перспективі. Зрозуміло, зазначена обставина свідчить про ймовірнісний характер стратегічної конкурентоспроможності, зважаючи на можливі зміни організаційного середовища у майбутньому, але таке підприємство володіє реальним потенціалом збереження своєї присутності на ринку.

В другому, підприємство може розраховувати на конкурентний статус у перспективі за умови набуття нових конкурентних переваг. Це шлях для суб'єктів, наявні конкурентні переваги яких, не мають перспектив дії у майбутньому. Ймовірність досягнення стратегічної конкурентоспроможності такого підприємства суттєво нижча і залежить від можливостей корпоративного менеджменту щодо оновлення існуючих переваг та вагомості нових, які мають забезпечити конкурентоспроможність підприємству впродовж тривалого часу у перспективі.

Отже, свідченням стратегічної конкурентоспроможності підприємства буде його діяльність на ринку у стратегічній перспективі, що, зрозуміло, не можна підтвердити у поточному періоді. Тому, ймовірнісний характер стратегічної конкурентоспроможності $\epsilon$ iï іманентною ознакою, яка має диференційований рівень в залежності від зовнішніх i внутрішніх організаційних умов господарювання.

Перспективний характер стратегічної конкурентоспроможності набуває конкретизованого прикладного значення в разі його детермінації, тобто, визначення тривалості періоду, який слід вважати стратегічним, і впродовж якого дане підприємство має забезпечити свою конкурентоспроможність.

В науковій літературі здебільшого керуються поняттям «стратегічності», виходячи з експертного визначення його тривалості, або обмежуються якісними характеристиками, на кшталт - «довгостроковий», «тривалий». Разом 3 цим період, який можна назвати стратегічним, є диференційованою ознакою, яка залежить від чинників, що впливають на формування і діяльність суб'єктів певного типу у визначеній сфері діяльності. Він не може бути персоніфікованим, але певний рівень групової індивідуалізації вбачається доречним.

Тривалість стратегічного періоду залежності від галузі економіки і обсягу діяльності підприємства. Логіка такого припущення полягає в об'єктивній різниці тривалості періоду, який претендує бути стратегічним, наприклад, для сталеливарних підприємств і підприємств торгівлі; невеликих роздрібних підприємств з обмеженим асортиментом товарів і гіпермаркетів, які реалізують десятки тисяч найменувань товарів і мають велику кількість постійних клієнтів.

Кожне із зазначених підприємств має свій формат стратегічного періоду. Його тривалість для сталеливарного підприємства визначається роками i десятиліттями, оскільки лише за цей час можуть відбутися значущі(стратегічні) 
зміни в технології, організації виробництва, трансформації конкурентного середовища, які впливають на його конкурентоспроможність. Конкурентоспроможність невеликих підприємств досить динамічна 3 огляду на швидкі зміну у внутрішньому організаційному середовищі і нестабільності їхніх конкурентних ринків, де представлено такі ж підприємства 3 ситуативними конкурентними можливостями.

Отже, стратегічним періодом слід вважати час, впродовж якого можуть відбутися зміни у конкурентному середовищі, які здатні вплинути на існування підприємства даного типу. Якщо виключити форс-мажорні непередбачувані події, то основним чинником впливу на збереження конкурентоспроможності підприємства $є$ поява нових конкурентів, здатних витіснити підприємство даного типу 3 ринку. Тому тривалість стратегічного періоду конкретного суб'єкта ринку знаходиться в межах часу на створення та початок виробничої діяльності подібного підприємства i середнім часом функціонування підприємств подібного типу на даному ринку. Стратегічний період слугує мірилом часу, за який може змінитися склад основних конкурентів, i як наслідок, характер конкурентних відносин на ринку. За цей період конкурентний ринок може трансформуватись настільки, що загрози існуванню багатьом діючим на ньому підприємствам стануть цілком реальними.

Визначення стратегічного періоду необхідне не лише для того, щоб знати час, впродовж якого, ймовірно, підприємство збереже свою конкурентоспроможність в разі визнання ii стратегічного характеру. Його тривалість має враховуватись при 3'ясуванні доцільної ретроспективи здійснення аналізу досягнутої конкурентоспроможності, що має передувати оцінці рівня стратегічної конкурентоспроможності.

Більшість дослідників стратегічної конкурентоспроможності відзначають ii потенційний характер, пов’язуючи його 3 невикористаними резервами, які мають забезпечити конкурентне положення підприємства у майбутньому. Це досить спірне положення, оскільки наявні резерви не завжди будуть використані у перспективі, а їхня поточна присутність може бути свідченням нездатністю менеджменту до реалізації корпоративних можливостей розвитку. За таких обставин навряд чи можна говорити про збереження конкурентоспроможності у майбутньому, коли виклики зовнішнього середовища будуть лише посилювати вимоги до якості управлінських рішень.

Потенційний характер стратегічної конкурентоспроможності є похідною від ймовірнісної перспективи збереження конкурентоспроможності підприємства, яка має підкріплюватися певними здатностями i позитивними об’єктивними, часто рентними, умовами господарювання - комплексом конкурентних переваг, що мають потенціал збереження у стратегічній перспективі. Тому основною ознакою потенціалу конкурентоспроможності слід вважати наявність у підприємства стійких конкурентних переваг. Але існує незаперечна складність ідентифікації і кількісної інтерпретації можливих результатів реалізації зазначених переваг.

Отже, стратегічна конкурентоспроможність відображає ймовірнісну перспективну здатності суб'єкта ринку зберігати комплекс конкурентних 
переваг (потенціал конкурентоспроможності), що забезпечить його конкурентоспроможність у стратегічному періоді. Вона має відносний характер, а отже є об'єктом оцінки з диференційованим рівнем, який визначається:

глибиною перспективи збереження конкурентоспроможності на основі наявних конкурентних переваг, яка вимірюється в одиницях часу;

ступенем стійкості конкурентних переваг до негативних змін середовища, яка $\epsilon$ якісною характеристикою, що відображає потенціал збереження конкурентоспроможності.

На відміну від досягнутої конкурентоспроможності, яка $\epsilon$ характеристикою минулої діяльності підприємства, іiі стратегічний формат зорієнтовано на перспективний період, впродовж якого суб'єкт здатен витримувати конкуренцію на ринку. Збільшення цього періоду є свідченням зростання стратегічної конкурентоспроможності підприємства.

Ступінь стійкості переваг підприємства $\epsilon$ якісною ознакою конкурентоспроможності, яка визначають потенціал ii захищеності від можливих змін зовнішнього оточення. Збільшення ступеня стійкості підприємства підвищує ймовірність збереження конкурентоспроможності у стратегічній перспективі.

Слід підкреслити, що наведені ознаки стратегічної конкурентоспроможності не можна розглядати відокремлено один від другого, оскільки вони не є самодостатніми. Так, збільшення глибини перспективи збереження конкурентоспроможності потребує відповідного зростання ступеня стійкості підприємства до негативних змін середовища, а зростання рівня стійкості наявних переваг не завжди забезпечить стратегічну конкурентоспроможність об'єкта 3 причини можливих конкурентних зрушень, що будуть потребувати набуття нових переваг з відповідними ознаками стійкості.

За умови відокремленої характеристики стратегічної конкурентоспроможності на основі однієї з розглянутих ознак, отримані результати не будуть достатніми для прийняття управлінських рішень 3 наступних причин:

- з знання глибини перспективи збереження конкурентоспроможності не враховує конкурентного потенціалу щодо протидії можливим зовнішнім змінам, що можуть суттєво зменшити період реального збереження конкурентоспроможності;

наявність інформації про ступінь стійкості підприємства до негативних змін середовища не дає уявлення щодо періоду, впродовж якого зазначена стійкість буде забезпечена.

Глибина стратегічної перспективи збереження конкурентоспроможності це диференційований часовий період, протягом якого підприємство, ймовірно, забезпечить рентабельну реалізацію виробленої продукції. Він визначається на основі екстраполяції основних показників досягнутої конкурентоспроможності - обсягу і рентабельності діяльності. Отримання коректного прогнозу по даних показниках на максимальну перспективу свідчить про час збереження конкурентоспроможності підприємством. Дана вимога стосується кожного 3 
показників конкурентоспроможності, оскільки відсутність реалізації готової продукціі, а також збиткова діяльність підприємства, є незаперечними ознаками його неконкурентоспроможності.

Даний метод оцінки глибина перспективи збереження конкурентоспроможності придатний для застосування у відносно стабільних умовах середовища. Непередбачувані зовнішні зміни можуть негативно вплинути на динаміку показників конкурентоспроможності, що порушить попередню тенденцію і унеможливить застосування екстраполяції. За таких умов визначення параметрів періоду збереження конкурентоспроможності можливе тільки за методом експертної оцінки.

Кількісна оцінка потенціалу збереження конкурентоспроможності пов’язана із складнощами, обумовленими відсутністю прямих параметричних характеристик стійкості конкурентних переваг підприємства • Застосування експертного методу ускладнить організаційну процедуру i не забезпечить об’єктивність оцінки стратегічної конкурентоспроможності підприємства. Рівень довіри до отриманих результатів навряд чи задовольнить серйозного дослідника, оскільки така оцінка буде переважно інтуїтивною, 3 огляду на складність предмету вивчення.

Вирішення даної проблеми може бути здійснено на основі ідентифікації опосередкованих ознак потенціалу стратегічної конкурентоспроможності, які мають відповідні параметри виміру. До них можна віднести:

- період функціонування діючого підприємства, що є свідченням його конкурентоспроможності за цей час;

- досягнутий рівень конкурентоспроможності на момент останньої оцінки;

- реалізація підприємством цільових параметрів розвитку у поточному періоді, що виявляється в ретроспективній динаміці досягнутої конкурентоспроможності(динамічна конкурентоспроможність).

Доцільність врахування періоду функціонування діючого підприємства випливає з логічності висновку, щодо більшого досвіду конкурентної діяльності тих підприємств, які діяли на ринку більший період часу і довели свою здатність виживати у конкурентному середовищі. Період функціонування діючого підприємства $є$ індивідуалізованою характеристикою окремого підприємства, збільшення якого свідчить про більшу ймовірність стратегічної конкурентоспроможності досліджуваного об'єкту.

Досягнутий рівень конкурентоспроможності $\epsilon$ диференційованою характеристикою здатності підприємства досягати конкурентного результату. Підприємства з високою досягнутою конкурентоспроможністю мають значно вищий потенціал збереження присутності на ринку в стратегічній перспективі у порівнянні з тими, хто має нижчі параметри. Ці підприємства мають резерв зниження конкурентоспроможності без ii втрати, якщо зовнішні зміни i внутрішні можливості стануть не сприятливими.

Позитивна ретроспективна динаміка досягнутої конкурентоспроможності підприємства, є свідченням більшої ймовірності збереження/посилення його конкурентного положення на ринку у перспективному стратегічному періоді у порівнянні 3 тими суб’єктами, які допустили зниження 
конкурентоспроможності. Конкурентний успіх підприємств, які змогли сформувати i реалізувати комплекс конкурентних переваг, що забезпечив зростаючу динаміку їхньої конкурентоспроможності, має певну інерцію, період збереження якого залежить від темпів росту досягнутої конкурентоспроможності. Це обумовлює доцільність диференційованої оцінки зазначеного зростання.

Крім того, наявність ретроспективної динаміка конкурентоспроможності $€$ необхідною умовою здійснення прогнозу конкурентного положення підприємства, а іiі зростаючий характер за наявності помітної тенденції ознакою потенціалу збереження конкурентоспроможності у стратегічній перспективі.

Окремо слід зазначення, що розглянуті передумови набувають прикладного значення лише за їх комплексного застосування. Так, значний період функціонування підприємства за негативної динаміки конкурентоспроможності $\epsilon$ ознакою можливості іiі втрати у перспективі. Позитивна ж динаміка конкурентоспроможності впродовж незначного періоду не гарантує збереження даної тенденції у стратегічній перспективі.

Тому кількісне вимірювання потенціалу стратегічної конкурентоспроможності (ПСК) доцільно здійснювати за інтегральним методом 3 використанням коефіцієнтів конкурентного досвіду (Кдс), досягнутої (Кд) і динамічної (Кдн) конкурентоспроможності підприємства:

$$
\Pi \text { ПК }=\sqrt[3]{ } \text { Кдс } \cdot \text { Кд } \cdot \text { Кдн }
$$

Базою порівняння за розрахунку коефіцієнту конкурентного досвіду має бути тривалість стратегічного періоду в роках (Тсп), визначеного для суб'єктів даного ринку:

$$
\text { Кдс }=\text { Тф : Тсп, }
$$

де: Тф - період функціонування досліджуваного підприємства, років.

Зростання значення даного показника свідчить про накопичений досвід забезпечення конкурентоспроможності і характеризує управлінський потенціал адекватного реагування на конкурентні виклики ринку.

Коефіцієнт досягнутої конкурентоспроможності визначається за даними звітного року діяльності підприємства:

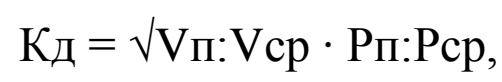

де: Vп - обсяг діяльності підприємства;

Vcp - середній обсяг діяльності підприємств на ринку;

Рп - рентабельність діяльності підприємства;

Рср - середня рентабельність діяльності підприємств на ринку.

Характер ретроспективної динаміки конкурентоспроможності (динамічної конкурентоспроможності) визначається за час, що відповідає тривалості стратегічного періоду: 


$$
\text { Кдн }=\sqrt{ } I \mathrm{v}_{\Pi}: I \mathrm{v}_{\mathrm{cp}} \cdot I \mathrm{p}_{\Pi}: I \mathrm{p}_{\mathrm{cp}},
$$

де: $I \mathrm{v}_{\text {п }}, \mathrm{p}_{\text {п }}-$ індекси, відповідно, обсягу і рентабельності підприємства;

$I \mathrm{v}_{\mathrm{cp}}, I \mathrm{p}_{\mathrm{cp}}-$ середні значення індексів обсягу і рентабельності підприємств на ринку.

Високий рівень потенціалу стратегічної конкурентоспроможності відповідає наступній умові:

$$
\text { ПСК }>1
$$

Даний метод дозволяє розрахувати параметри потенціалу стратегічної конкурентоспроможності підприємства, які можна використати при диференціації досліджуваних підприємств і їх групуванні за певними ознаками.

3 метою отримання аналітичних результатів і прийняття управлінських рішень доцільно надати якісну характеристику конфігурації складових потенціалу стратегічної конкурентоспроможності і з'ясувати обставини, що обумовили отримання того чи іншого результату (табл. 1).

Таблиця 1

Конфігурація складових потенціалу стратегічної конкурентоспроможності

\begin{tabular}{|c|c|c|c|}
\hline $\begin{array}{c}\text { Кдс, } \\
\text { в- високе; } \\
\text { н- низьке }\end{array}$ & $\begin{array}{c}\text { Кд, } \\
\text { в- високе; } \\
\text { н - низьке }\end{array}$ & $\begin{array}{l}\text { Кдн, } \\
\text { в- високе; } \\
\text { н - низьке }\end{array}$ & Оцінка ПСК \\
\hline \multirow{4}{*}{ Кдс ${ }^{\mathrm{B}}$} & \multirow[b]{2}{*}{ Кд ${ }^{\mathrm{B}} \mathrm{K}^{\mathrm{B}}$} & $\mathrm{Kдc}^{\mathrm{B}} \mathrm{Kд}^{\mathrm{B}} К д \mathrm{H}^{\mathrm{B}}$ & Надвисока \\
\hline & & Кдс ${ }^{\mathrm{B}} \mathrm{K}^{\mathrm{B}}{ }^{\mathrm{K}}$ дн $^{\mathrm{H}}$ & Висока з негативним прогнозом \\
\hline & \multirow[b]{2}{*}{ Кдс ${ }^{\mathrm{B}} \mathrm{K}^{\mathrm{H}}$} & Кдс ${ }^{\mathrm{B}} \mathrm{K}^{\mathrm{H}}{ }^{\mathrm{K}} д \mathrm{H}^{\mathrm{B}}$ & Середня з позитивним прогнозом \\
\hline & & Кдс ${ }^{\mathrm{B}} \mathrm{K}^{\mathrm{H}}{ }^{\mathrm{K}}$ дн $^{\mathrm{H}}$ & Середня з негативним прогнозом \\
\hline \multirow{4}{*}{ Кдс ${ }^{\mathrm{H}}$} & \multirow[b]{2}{*}{ Кдс ${ }^{\mathrm{H}} \mathrm{K}^{\mathrm{B}}$} & $\mathrm{Kдc}^{\mathrm{H}} \mathrm{K}^{\mathrm{B}}{ }^{\mathrm{K}} д \mathrm{H}^{\mathrm{B}}$ & Середня з позитивним прогнозом \\
\hline & & Кдс ${ }^{\mathrm{H}} \mathrm{K}^{\mathrm{B}}{ }^{\mathrm{K}}$ дн $^{\mathrm{H}}$ & Середня з негативним прогнозом \\
\hline & \multirow[b]{2}{*}{ Кдс ${ }^{\mathrm{H}} К д^{\mathrm{H}}$} & Кдс ${ }^{\mathrm{H}} К д^{\mathrm{H}} К д \mathrm{H}^{\mathrm{B}}$ & Низька з позитивним прогнозом \\
\hline & & Кдн ${ }^{\mathrm{H}}$ Кдс ${ }^{\mathrm{H}} \mathrm{K}^{\mathrm{H}}$ & Наднизька \\
\hline
\end{tabular}
підприємства та їхня оцінка

Дослідження отриманих варіантів конфігурації дозволяє надати якісну характеристику потенціалу стратегічної конкурентоспроможності підприємства. Особливу увагу слід звернути на прогнозні характеристики ПСК, які дозволяють заздалегідь прийняти управлінські рішення задля виправлення ситуації.

Здійснену оцінку було надано виходячи з однакової значимості досвіду роботи (Кдс) і досягнутого рівня конкурентоспроможності (Кд). За умови передбачення суттєвих змін у зовнішньому середовищі значимість досвіду може бути знижено, а оцінку ПСК уточнено.

Змістовні аналітичні висновки можна отримати при поєднання характеристик потенціалу i глибина перспективи збереження конкурентоспроможності, визначеної за методом екстраполяції показників конкурентоспроможності підприємства (табл. 2). 
Якщо не брати до уваги неможливі варіанти, які поєднують ознаки відсутності стратегічної конкурентоспроможності 3 високими значеннями динамічної конкурентоспроможності, а також, необмеженої у часі конкурентоспроможності 3 негативною динамічною конкурентоспроможністю, отримаємо 12 реалістичних конфігурацій досліджуваних характеристик стратегічної конкурентоспроможності підприємств.

Стратегічно конкурентоспроможні підприємства можуть мати обмежений - в разі знижуваної лінії тренду i, необмежений - за зростаючого тренду, період конкурентоспроможності. Якщо прогноз часу функціонування підприємства менший за стратегічний період, такий суб'єкт не володіє стратегічною конкурентоспроможністю.

Сформульовані аналітичні висновки мають узагальнюючий характер i потребують змістовної конкретизації 3 огляду на конкурентне положення кожного підприємства.

Таблиця 2

Аналітичне оцінювання варіантів співвідношення потенціалу та періоду стратегічної конкурентоспроможності підприємства

\begin{tabular}{|c|c|c|}
\hline $\begin{array}{c}\text { Потенціал } \\
\text { стратегічної } \\
\text { конкуренто- } \\
\text { спроможності }\end{array}$ & $\begin{array}{c}\text { Глибина } \\
\text { стратегічної } \\
\text { перспективи } \\
\text { збереження } \\
\text { конкурентоспромож } \\
\text { ності }\end{array}$ & Аналітичні висновки \\
\hline $\mathrm{Kдc}^{\mathrm{B}} \mathrm{K}^{\mathrm{B}} К д \mathrm{H}^{\mathrm{B}}$ & необмежена & $\begin{array}{l}\text { Стратегічно конкурентоспроможне підприємство } \\
\text { з необмеженим періодом }\end{array}$ \\
\hline \multirow[b]{2}{*}{ Кдс ${ }^{\mathrm{B}} К д^{\mathrm{B}} К д н^{\mathrm{H}}$} & відсутня & $\begin{array}{l}\text { Швидке зниження конкурентоспроможності } \\
\text { зрілого підприємства загрожує його існуванню }\end{array}$ \\
\hline & обмежена & $\begin{array}{l}\text { Швидке зниження конкурентоспроможності } \\
\text { зрілого підприємства потребує попереджуючих } \\
\text { управлінських дій }\end{array}$ \\
\hline Кдс ${ }^{\mathrm{B}} \mathrm{K}^{\mathrm{H}}{ }^{\mathrm{K}} \mathrm{H}^{\mathrm{B}}$ & необмежена & $\begin{array}{l}\text { Стратегічно конкурентоспроможне підприємство } \\
3 \text { активно зростаючою конкурентоспроможністю }\end{array}$ \\
\hline \multirow[t]{2}{*}{ Кдс ${ }^{\mathrm{B}} \mathrm{K}^{\mathrm{H}}$ Кдн ${ }^{\mathrm{H}}$} & відсутня & $\begin{array}{l}\text { Досвід підприємства не забезпечив його } \\
\text { стратегічної конкурентоспроможності }\end{array}$ \\
\hline & обмежена & $\begin{array}{l}\text { Зниження конкурентоспроможності складає } \\
\text { загрозу у стратегічній перспективі }\end{array}$ \\
\hline Кдс ${ }^{\mathrm{H}} \mathrm{K}^{\mathrm{B}}{ }^{\mathrm{K}}$ дн $^{\mathrm{B}}$ & необмежена & $\begin{array}{l}\text { Молоде успішне підприємство з надактивним } \\
\text { конкурентним розвитком }\end{array}$ \\
\hline \multirow[t]{2}{*}{ Кдс ${ }^{\mathrm{H}} К д^{\mathrm{B}} К д \mathrm{H}^{\mathrm{H}}$} & відсутня & $\begin{array}{l}\text { Молоде підприємство, що досягло високої } \\
\text { конкурентоспроможності перебуває в процесі } \\
\text { згортання своєї діяльності }\end{array}$ \\
\hline & обмежена & $\begin{array}{l}\text { Молоде підприємство, що досягло високої } \\
\text { конкурентоспроможності відчуває стратегічні } \\
\text { загрози }\end{array}$ \\
\hline
\end{tabular}




\begin{tabular}{|c|c|l|}
\hline \multirow{2}{*}{ Кдс $^{\mathrm{H}} \mathrm{K}^{\mathrm{H}}{ }^{\mathrm{K}}$ дн $^{\mathrm{B}}$} & необмежена & $\begin{array}{l}\text { Перспективне молоде підприємство, що може } \\
\text { досягти високої конкурентоспроможності }\end{array}$ \\
\hline \multirow{2}{*}{ Кдн ${ }^{\mathrm{H}} \mathrm{Kдс}^{\mathrm{H}} \mathrm{K}^{\mathrm{H}}$} & відсутня & $\begin{array}{l}\text { Перспективи збереження } \\
\text { конкурентоспроможності наднизькі }\end{array}$ \\
\cline { 2 - 3 } & обмежена & $\begin{array}{l}\text { Збереження конкурентоспроможності потребує } \\
\text { активних зусиль }\end{array}$ \\
\hline
\end{tabular}

Висновки. Стратегічна конкурентоспроможність відображає ймовірнісну перспективну здатності суб'єкта ринку зберігати комплекс конкурентних переваг (потенціал конкурентоспроможності), що забезпечить його конкурентоспроможність у стратегічному періоді.

Стратегічним періодом слід вважати час, впродовж якого можуть відбутися зміни у конкурентному середовищі, які здатні вплинути на існування підприємства даного типу.

Стратегічна конкурентоспроможність визначається глибиною перспективи збереження конкурентоспроможності i ступенем стійкості конкурентних переваг, що відображає потенціал збереження конкурентоспроможності.

Потенціал стратегічної конкурентоспроможності характеризується: тривалістю часу функціонування діючого підприємства, досягнутим i динамічним рівнем конкурентоспроможності. Його кількісне вимірювання доцільно здійснювати за інтегральним методом.

Задля отримання аналітичних результатів і прийняття управлінських рішень необхідно надати якісну характеристику конфігурації складових стратегічної конкурентоспроможності за методом багатомірного матричного позиціонування.

Запропонований підхід дозволяє перевести у площину аналітичної конкретики якісні характеристики стратегічної конкурентоспроможності підприємства і оцінити перспективу іiі збереження впродовж визначеного стратегічного періоду.

\section{Література:} $806 \mathrm{c}$.

1. Портер М. Конкуренция. Пер.с англ. - М.: Издательский дом «Вильямс». - 2006. -

2. Рохчин В.Е., Ветрова Е.Н., Полянский А.В. Управление стратегической конкурентоспособностью промышлен-ного предприятия на основе развития его потенциала / под редакцией д-ра экон. наук, профессо-ра А.Е. Карлика. - СПб. : Изд-во СПбГУЭФ, 2012. $262 \mathrm{c.}$

3. Фатхутдинов Р.. Стратегическая конкурентоспособность и экономика России // Общество и экономика. - №1. - 2003 - С. $31-43$

4. Шершньова 3.С., Оборська С.В. Стратегічне управління: Навч.посібник. - КНЕУ, 1999. -384 c.

5. Шпанко А. Про сутність поняття "стратегічна конкурентоспроможність"// Економіка України. - 2007. - № 6. - С. 45-49 